\title{
Impact of ERT and Follow up of 17 Patients from the Same Family with Mild form of MPS II
}

Bruno de Oliveira Stephan ( $\nabla$ bruno.stephan@hc.fm.usp.br)

USP ICr: Universidade de Sao Paulo Instituto da Crianca https://orcid.org/0000-0002-5711-0230

\section{Caio Robledo Quaio}

USP ICr: Universidade de Sao Paulo Instituto da Crianca

\section{Gustavo Marquezani Spolador}

USP ICr: Universidade de Sao Paulo Instituto da Crianca

\section{Ana Carolina de Paula}

USP ICr: Universidade de Sao Paulo Instituto da Crianca

\section{Marco Antônio Curiati}

Universidade Federal de Sao Paulo Escola Paulista de Medicina

\section{Ana Maria Martins}

Universidade Federal de Sao Paulo Escola Paulista de Medicina

\section{Gabriela Nunes Leal}

USP ICr: Universidade de Sao Paulo Instituto da Crianca

\section{Artur Tenorio}

Universidade de Sao Paulo Hospital das Clinicas

\section{Simone Finzi}

Universidade de Sao Paulo Hospital das Clinicas

\section{Flavia Teixeira Chimelo}

USP FM: Universidade de Sao Paulo Faculdade de Medicina

\section{Carla Gentile Matas}

USP FM: Universidade de Sao Paulo Faculdade de Medicina

\section{Rachel Sayuri Honjo}

USP ICr: Universidade de Sao Paulo Instituto da Crianca

\section{Debora Romeo Bertola}

USP ICr: Universidade de Sao Paulo Instituto da Crianca

Chong Ae Kim

USP ICr: Universidade de Sao Paulo Instituto da Crianca

\section{Research}


Keywords: Iysosomal enzyme iduronate-2- sulfatase (IDS), glycosaminoglycans (GAGs), Enzyme Replacement Therapy (ERT),

Posted Date: June 14th, 2021

DOI: https://doi.org/10.21203/rs.3.rs-540976/v1

License: (c) (i) This work is licensed under a Creative Commons Attribution 4.0 International License. Read Full License 


\section{Abstract}

Background: Mucopolysaccharidosis type II, also known as Hunter syndrome, is a rare X-linked recessive disorder caused by deficiency of the lysosomal enzyme iduronate-2- sulfatase (IDS), leading to progressive accumulation of glycosaminoglycans (GAGs) in several organs. Over the years, Enzyme Replacement Therapy (ERT) has provided significant benefit for patients, retarding natural progression of the disease.

Results: We evaluated 17 patients from the same family with a mild form of MPS type Il; proband had developed acute decompensated heart failure refractory to clinical measurements at 23 years and needed a rather urgent heart transplant; however, he died from surgery complications shortly after the procedure. Nevertheless, subsequently to his tragic death, 16 affected male relatives were detected after biochemical tests identifying low or absent activity of IDS enzyme and confirmed by molecular analysis of IDS gene.

Following diagnosis, different options of treatment were decided: 6 patients started

ERT with Elaprase ${ }^{\circledR}$ (Idursulfase) soon after, while other 10 remained without ERT;

eventually, 4 patients among the latter group began ERT with Hunterase ${ }^{\circledR}$ (Idursulfase Beta). None presented adverse effects to neither forms of the enzyme. Among the 6 individuals without any ERT, two died of natural causes, after reaching 70 years. Despite the variable phenotype within same family (mainly heart dysfunctions and carpal tunnel syndrome), all 14 remaining patients are alive with independent style of life.

Conclusion: Here we report the variable progress of disease with and without ERT in a large Brazilian family with attenuated form of MPS II, harboring the same missense variant in the IDS gene.

\section{Introduction}

Mucopolysaccharidosis type II (MPS II, OMIM 607014; also known as Hunter syndrome) is a rare X-linked recessive disorder caused by a deficiency of the lysosomal enzyme iduronate-2-sulfatase (IDS), leading to the progressive accumulation of glycosaminoglycans (GAGs) in several organs. The chronic deposition of undegraded GAGs in the connective tissue contributes to the progressive clinical course of the syndrome with a variable degree of severity and life expectancy. Increased urinary excretion of dermatan and heparan sulfate, low or absent activity of IDS enzyme and molecular analysis of IDS gene may confirm the diagnosis ${ }^{12^{\prime} 3^{\prime} 4}$.

We have previously reported a large Brazilian family with 17 individuals affected by a very attenuated form of MPS II, all of who harbored the p.A77D in the IDS gene》. The diagnosis of this family was only possible because the proband had developed acute decompensated heart failure refractory to clinical measurements and required heart transplant. His clinical evaluation before the procedure showed mild coarse face, hepatomegaly, joint stiffness of the shoulders; biochemical assays showed an increased 
excretion of GAGs in the urine and a deficiency of IDS activity in leukocytes, confirming the diagnosis of MPS II. The first heart transplant in a patient with MPS II was then performed using bicaval orthotopic heart transplantation technique, but unfortunately, the patient died from primary left ventricular failure 2 days after the surgery $\llbracket$. In the proband's family, 16 other affected individuals with the mild form of MPS II and 14 female carriers of the trait were discovered after this episode.

The severe form of MPS II is characterized by facial dysmorphism, short stature, hepatosplenomegaly, hernias, stiff joints and contractures, cardiac valve disease, obstructive respiratory complications, chronic diarrhea, hearing loss, communicating hydrocephalus, cognitive impairment and death by progressive airway obstruction or cardiac dysfunction between the ages of 10 and 15 years ${ }^{1} 2^{\prime} \otimes$. However, the mild (or

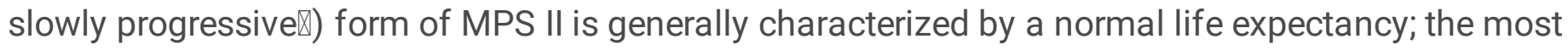
serious complications in these patients are usually secondary to heart defects, which may lead to premature death in some cases.

The objective of this article is to describe follow up of this large family, divided in members with two different enzyme replacement therapy and others without enzyme therapy (ERT).

\section{Method}

\section{Clinical information and biochemical analysis}

This study was conducted on 17 related patients from one single family in which the diagnosis of MPS II was established after the demonstration of concomitant increased urinary excretion of dermatan and heparan sulfate, low or absent activity of IDS enzyme and molecular analysis of IDS gene.

All patients were followed by clinical geneticist. Patients received genetics counseling and signed a written informed consent. If the patient was underage, the parents or legal representative provided written consent. This study was approved by the ethics committee of our institution.

Prospective data has been collected from these patients for the last decade.

\section{Molecular analysis}

Genomic DNA was isolated from peripheral blood lymphocytes; exonic regions and exon-intron boundaries of IDS gene were then amplified by PCR and sequenced using Sanger technique and standard protocols.

\section{Variant classification}

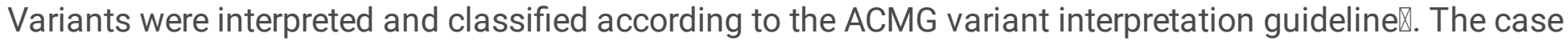
was only considered as diagnosed when pathogenic or likely pathogenic variant were observed in a gene that was associated with the phenotype in the studied individual, with compatible zygosity and in an adequate inheritance pattern. 
The 1000 Genomes project database (http://www.1000genomes.org), including all human genetic variations from the dbSNP short genetic variations database (https://www.ncbi.nlm.nih.gov/snp/) and the ExAC Browser of the Exome Aggregation Consortium, which provides a data set spanning over 60,000 unrelated individuals (http://exac.broadinstitute.org), were used to evaluate the polymorphic status of the identified genetic alterations.

\section{Enzyme replacement therapy and follow-up protocol}

Following diagnosis in 16 males from the family of the proband, 10 of them started ERT: 6 received Idursulfase (Elaprase ${ }^{\circledR}$ ) and the other 4, Idursulfase Beta (Hunterase ${ }^{\circledR}$ ). Other 6 patients did not receive any ERT; two died of natural causes, after reaching 70 years.

\section{Results}

\section{Clinical and biochemical data}

We report the available clinical and biochemical information collected for each patient on the table attached. The previously asymptomatic proband had an ordinary life until 23 years of age, making it possible for him to graduate from university. He was admitted at the Cardiologic Intensive Care Unit due to acute decompensated heart failure progressing within 1 month; physical exam at that time showed normal height, weight and occipital frontal circumference (OFC: $56 \mathrm{~cm}$ ), as well as a mild coarse face, hepatomegaly and joint stiffness of the shoulders. Biochemical assays showed an increased excretion of GAGs in the urine and a deficiency of IDS activity in leukocytes, confirming the diagnosis of MPS type II. Echocardiogram demonstrated thickened valves with severe mitral regurgitation, severe left ventricular dilatation and severe ventricular dysfunction. Since his heart failure was refractory to clinical management, a heart transplant was indicated; unfortunately, patient died of primary graft failure 2 days after the surgery. Postmortem histopathological analysis of the myocardium by electron microscopy revealed that GAGs accumulated in the interstitium of the myocytes $\llbracket$.

Following the proband's diagnosis and almost immediate death, 16 other affected individuals and 14 female carriers were identified in the family pedigree study (Fig. 1). Clinical, biochemical, and molecular tests were conducted among the living family members. At the time, we examined 14 affected patients, among whom nine were adults over 18 years of age, plus three teenagers and one-year-old pair of identical twins. The age of diagnosis was between 8 months and 35 years, with a mean of 18,6 years.

Anthropometric measurements, including body-mass index (BMI), were within normal percentiles for most of the patients, though two adults presented short stature (heights of 153 and $151 \mathrm{~cm}$ from P5 and P15, respectively) and other one showed signs of macrocephaly (OFC $>60 \mathrm{~cm}$ ). Mild coarse facies proved to be a universal finding, whereas hepatomegaly was clinically observed only in the proband (probably secondary to acute decompensated heart failure), although $60 \%$ presented hepatosplenomegaly at some point of life. No one presented lumbar gibbus, claw hands, or deformities other than mild articular restriction, such as stiffness of shoulders and carpal tunnel syndrome. 
Despite only the proband becoming frankly symptomatic and evolving to cardiac failure, all except one (P6) of the living 14 men presented some degree of heart damage. The tricuspid valve was involved in six patients; the aortic valve, in nine; and the mitral valve, in twelve of them. Additionally, one individual presented ventricular septal defect.

Neurologic signs of the disease were suspected in only one patient (P11), who presented a remarkable speech delay (as he learnt to talk only with 5 years); however, his condition was later attributed to repeated crisis of otitis media and severe hearing disability. Of the 14 patients, 8 underwent assessment of the peripheral and central auditory pathways; $62.5 \%$ had mild to moderate hearing loss, with the sensorineural type being the most frequent finding. Regarding the assessment of the central auditory pathway, $87.5 \%$ showed changes.

All adults had normal cognitive development (including P11), making it possible for them to graduate from normal school and perform satisfactorily in their ordinary jobs. As expected, the 14 female carriers did not present any signs of disease activity.

Initial urinary levels of GAGs varied from 108 to $683 \mu \mathrm{g} / \mathrm{mg}$ creatinine (normal: $13-45$ ), with a mean of $239,8 \mu \mathrm{g} / \mathrm{mg}$; for those patients which received ERT, levels reached a mean of $95,1 \mu \mathrm{g} / \mathrm{mg}$ after its introduction. Enzymatic dosage through IDS activity in leukocytes ranged from undetectable to 4,3 $\mathrm{nmol} / 4 \mathrm{~h}$ mg protein, which represents a maximum of $13,8 \%$ of the minimal value usually seen in the normal population (value of reference: $31-110 \mathrm{nmol} / 4 \mathrm{~h}$ mg protein).

IDS molecular analysis

Segregation analysis of this family shows a perfect correlation, which is highly suggestive of cosegregation of this variant with affected individuals. Female patients suspected of being obligatory carriers, as well as patients presenting biochemical evidence of diminished IDS enzyme activity, were submitted to molecular analysis, all of them harboring the same hemizygous variant (p.A77D) in IDS gene.

\section{Variant classification}

Firstly, the variant was located in a mutational hotspot (PM1); additionally, this was a missense in a gene with low rate of benign missense variants, for which such kind of finding is a well-known mechanism of disease (PP2). It was also in perfect co-segregation with the disease in multiple affected family members (PP1) and phenotype was highly specific for gene as well (PP4). Finally, not only the variant has not been found in control databases (PM2), but also multiple lines of computational evidence supported a deleterious effect (PP3). Hence, according to the ACMG variant interpretation guideline $\mathbb{Z}$, the variant was classified as likely pathogenic.

\section{Enzyme replacement therapy and follow-up protocol}

Among the 10 patients that received ERT, 6 were given Idursulfase (Elaprase ${ }^{\circledR}$ ) and, other 4, Idursulfase Beta (Hunterase ${ }^{\circledR}$ ); age of introduction of treatment was 1 to 26 and 27 to 37 years, respectively. In 
accordance with most of the reviews ${ }^{4}$, there were no significant differences between the medications chosen. Out of the 6 patients without ERT, two elderly died of natural causes.

\section{Discussion}

This large Brazilian family with 17 individuals displays a very attenuated form of MPS II, with normal cognitive development and preserved quality of life. The diagnosis of this condition in otherwise asymptomatic people was only possible because of the proband's acute decompensated heart failure. This disease has been traditionally classified into attenuated and severe subtypes, although variations of severity between these two extremes have been observed.

Cardiovascular involvement was the most common serious complication of the disease in this family, although the proband was the only person to present major cardiovascular symptoms. The fast progression of his heart failure at the young age of 23 years was conspicuous. The failure of the clinical management plus the severity of heart involvement determined his need for a heart transplantation, which was performed for the first time in the context of MPS II. Unfortunately, the surgical approach failed in its objective, as the patient died of primary graft failure at the second day of postoperative.

A remarkable variability of heart involvement was observed among affected individuals. The proband's 28-year-old brother had only mild aortic regurgitation, while his 19-year-old cousin had a normal echocardiogram. Interestingly, despite the fact that other family members had severe valvar lesion in echocardiography studies, they had no complaints or significative symptoms of heart failure. In the literature, symptomatic individuals constitute more than $80 \%$ of all MPS II patients, whereas valvar disease may be found in up to $60 \%$ $₫$. Considering the importance of cardiovascular involvement in MPS II, physicians must always be aware of periodically monitoring heart complications during the follow-up of these patients through comprehensive clinical examination and routine echocardiography, always keeping in mind that some degree of the disease is usually expected, even in healthy patients.

Among surgical interventions, resection of adenoid and/or tonsil tissues was by far the most common procedure; since airway obstruction is progressive and frequent in MPS $\mathrm{II}^{11}$, surgical correction of hypertrophy of the adenoid and tonsil tissue was necessary in nine patients. Likewise, hernias (either umbilical or inguinal) are very common in this disease, demanding surgical intervention in ten individuals.

Articular restriction was noteworthy as well, affecting the shoulders in most individuals; in the mild form of MPS II, joint contractures usually involve the upper more prominently than the lower extremities.

As expected for MPS II patients, none of the individuals had corneal opacities. However, retinopathies were reported: two patients (P10 and P12) presented retinitis pigmentosa and were submitted to peripheral iridotomy due to the primary angle closure (PAC), while other one (P13) showed optic nerve swelling, which responded well to clinical treatment. Besides that, hypermetropia was present in six patients, with retinal detachment secondary to trauma occurring in one of them (P8). 
Although life expectancy is close to normal in less severely affected individuals and such individuals may reproduce, as previously reported ${ }^{12^{1} 13^{1} 14}$, authors believe that sensorineural hearing impairment is progressive and relates to cochlear fragility due to cell cilia dysfunction ${ }^{15,16,17}$; those findings emphasize the importance of referring these patients for an audiological evaluation, as well as monitoring from an auditory perspective.

As a matter of fact, the two affected seniors we identified died of natural causes at advanced ages (both older than 70 years old). The presentation of MPS II in these two individuals must have been mild enough to allow them to procreate and have long normal lives.

According to most sources, it seems to be no clear genotype-phenotype correlation in MPS II. From over 650 variants in IDS reported, nearly half are missense mutations ${ }^{4}$, like the one reported here. However, it is important to point out that the severe forms of the disease are usually associated with mutations that result in complete absence of the enzyme activity, such as nonsense and splicing variants, as well as large CNVs or complex rearrangements.

To this date, the specific mutation of this family (p.A77D) remains unreported by other studies or laboratories, according to databases such as the LOVD (Leiden Open Variant Database). In addition, the analysis from over a dozen silico prediction platforms (including REVEL and MutationTaster) indicate that this variant has, indeed, a disease-causing effect.

Regarding treatment, for many decades following Hunter's initial description of MPS II (back in 1917), there was no effective therapy for the disease, and management was restricted to a palliative approach. Hematopoietic stem-cell transplantation, which has been a major advance in the treatment of other forms of MPS in the last decades, seems to be quite ineffective for MPS II patients. Various forms of gene therapy (from viral vectors to substrate reduction therapies), although promising, remain distant for the clinical scenario for MPS II ${ }^{4}$ so far.

Fortunately, in the last fourteen years, the advent of enzyme replacement therapy (ERT) has changed the clinical approach of MPS II, adding the possibility of improving the degradation and excretion of GAGs. Given it postpones the systemic development and natural history of the disease, ERT has become the standard of care for MPS II and reinforced the importance of early diagnosis. However, many doubts about its application continue unsolved.

Considering urinary levels of GAGs do not seem to have a clear direct correlation with the clinical severity of disease and ERT for MPS II (or other types of mucopolysaccharidosis) frequently do not normalize GAG levels ${ }^{18}$, therapeutical response tends to be quite difficult to measure through laboratorial parameters. Additionally, long-term benefits are somewhat limited when applied to patients with the severe phenotype, since it's more and more evident that plasma infusions won't penetrate the blood-brain barrier (BBB) and thus are unable to prevent the advance of the disease in central nervous system (CNS) ${ }^{19} \cdot 20$. At last, the age at which ERT should be initiated and whether asymptomatic individuals presenting the mild form of MPS II must be treated remains uncertain ${ }^{4^{\prime} 19}{ }^{\prime 2} 21$. 
On regards towards our family, following diagnosis 10 patients started ERT (Fig. 2/ Table 1): 6 of them were given Idursulfase (Elaprase ${ }^{\circledR}$ ) and the other 4, Idursulfase Beta (Hunterase ${ }^{\circledR}$ ). In accordance with most of the reviews ${ }^{4}$, none of the men under ERT presented any relevant adverse effect to neither of the two enzymes, to this date (after more than a decade of treatment). Even though the echocardiographic and ophthalmologic findings seem to be more severe in the second group, it is important to point out that the patients in the first group were not only considerably younger, but also received medication for far more time (total time of treatment of 11 against 4 years, respectively). In fact, these older patients opted to initiate ERT majorly due to worsening nocturne vision; at the time, due to bureaucratic reasons, Idursulfase Beta (Hunterase ${ }^{\circledR}$ ) was in a disposal and easier to access than Idursulfase (Elaprase $\left.{ }^{\circledR}\right)$.

In this scenario, we detected some minor alterations (mild mitral insufficiency) in the early stages of ERT (at age of 4) of our pair of identical twins in the first group; however, after their last appointment (at age of 11), only one of the twins (P3) persisted with the valvopathy, while the other (P2) revealed a rather normal echocardiogram. Despite this peculiarity, both of them (who are now 12 years old) always had an unremarkable clinical evaluation. Considering the natural progression of disease, we believe that these contradictory findings of $\mathrm{P} 2$ were secondary to multiple echocardiograms performed by different cardiologists.

Other than that, we could not find other significant differences between the two sets of patients; indeed, as most data suggests $22,23,24$ both drugs appear overall equally efficient and well tolerated. Comparatively, progress of the disease was rather uneventful in the four patients without ERT (Fig. 3/ Table 2), regardless of their advanced age (all over 40 years). Despite the variable phenotype (mainly heart dysfunctions and carpal tunnel syndrome), all 14 remaining living patients are still clinically healthy and have an independent style of life.

\section{Conclusion}

Considering the variability in the progression and the clinical phenotype of MPS II, we can see that even individuals of the same family, presenting the same identical mutation, might manifest the attenuated form of the disease quite differently, as observed in this group. Like mentioned before, the p.A77D missense mutation of IDS gene described in here has not been published before and probably allowed residual enzyme activity enough to prevent the severe form of MPS II, sparing patients of neurological or any other major impairment.

After a careful analysis of our familial cases with 17 individuals displaying a very attenuated form of disease, the practical impact of ERT remains surrounded by uncertainty. For the 10 individuals receiving ERT, both types of Idursulfase showed similar results and none adverse effects, while in the other 4 living patients without any ERT, progression of disease continued rather slow. Overall, the difference on the clinical outcome between those groups was minimal. 
Nevertheless, considering the tragic outcome of the proband, it is our opinion that such form of therapy should always be offered. Therefore, as most of reviews suggest, such decision should still be secondary to the clinical condition of each patient.

In conclusion, in this large family with a very attenuated form of MPS II and a variable degree of clinical manifestations, it is noteworthy that several affected individuals have remained asymptomatic even at advanced ages without ERT.

\section{Declarations}

Ethics approval and consent to participate: All patients were followed by clinical geneticist. Written consent was obtained from all participants. This study was approved by the ethics committee of our institution. There are no conflicts of interest to disclose.

Consent for publication: Patients received genetics counseling and signed a written informed consent. If the patient was underage, the parents or legal representative provided written consent.

Availability of data and materials: Prospective data has been collected from these patients for the last decade. Please contact author for data requests.

Funding: Funding information is not applicable.

Authors' contributions:

Mr. Bruno de Oliveira Stephan, MD - Contributed to the conception and design of the article, as well as the analysis and interpretation of data.

Mr. Gustavo Marquezani Spolador, MD - Contributed to the conception and design of the article, as well as the analysis and interpretation of data.

Mr. Caio Robledo Quaio, MD, MBA - Contributed to the conception and design of the article, as well as the analysis and interpretation of data.

Ms. Ana Carolina de Paula, MD - Contributed to the analysis and interpretation of data, specially concerning the clinical and genetic evaluation of the patients.

Mr. Marco Curiati, MD - Contributed to the analysis and interpretation of data, specially concerning the clinical and genetic evaluation of the patients.

Ms. Ana Maria Martins, MD, PhD - Contributed to the analysis and interpretation of data, specially concerning the clinical and genetic evaluation of the patients.

Ms. Gabriela Nunes Leal, MD, PhD - Contributed to the analysis and interpretation of data, specially concerning the echocardiographic evaluation of the patients. 
Mr. Artur Tenorio, MD - Contributed to the analysis and interpretation of data, specially concerning the ophthalmological evaluation of the patients.

Ms. Simone Finzi, MD, PhD - Contributed to the analysis and interpretation of data, specially concerning the ophthalmological evaluation of the patients.

Ms. Flavia Teixeira Chimelo, Master's degree in Phonoaudiology - Contributed to the analysis and interpretation of data, specially concerning the audiological evaluation of the patients.

Ms. Carla Gentile Matas, Doctor's degree in Phonoaudiology - Contributed to the analysis and interpretation of data, specially concerning the audiological evaluation of the patients.

Ms. Rachel Sayuri Honjo, MD, PhD - Contributed to the draft and critical revision of the article.

Ms. Debora Romeo Bertola, MD, PhD - Contributed to the draft and critical revision of the article.

Ms. Chong Ae Kim, MD, PhD - Contributed to the draft and critical revision of the article.

Acknowledgements: Not applicable.

\section{References}

1. Martin R, Beck M, Eng C, Giugliani R, Harmatz P, Munoz V, Muenzer J. Recognition and Diagnosis of Mucopolysaccharidosis II (Hunter Syndrome). PEDIATRICS. 2008;121(2):e377-86. doi:10.1542/peds.2007-1350.

2. Scarpa M. (2011) Mucopolysaccharidosis Type II. In: GeneReviews at GeneTests - Medical Genetics Information Resource (database online). Copyright, University of Washington, Seattle. 1997-2011. https://www.ncbi.nlm.nih.gov/books/NBK1274/.

3. Stapleton M, Arunkumar N, Kubaski F, Mason RW, Tadao O, Tomatsu S. Clinical presentation and diagnosis of mucopolysaccharidoses. Mol Genet Metab. 2018. doi:10.1016/j.ymgme.2018.01.003.

4. D’Avanzo F, Rigon L, Zanetti A, Tomanin R. Mucopolysaccharidosis Type II: One Hundred Years of Research, Diagnosis, and Treatment. Int J Mol Sci. 2020;21(4):1258. doi:10.3390/ijms21041258.

5. Quaio CRDC, Grinberg H, Vieira MLC, Paula AC, Leal GN, Gomy I, ... Kim CA. Report of a Large Brazilian Family With a Very Attenuated Form of Hunter Syndrome (MPS II). JIMD Reports -. Case Research Reports. 2011;2012/1:125-8. doi:10.1007/8904_2011_90.

6. Grinberg H, Quaio CRDC, Avila MS, Ferreira SMA, Vieira MLC, Benvenuti LA, ... Bocchi EA. The first cardiac transplant experience in a patient with mucopolysaccharidosis. Cardiovascular Pathology. 2012;21(4):358-60. doi:10.1016/j.carpath.2011.10.004.

7. Muenzer J, Beck M, Eng CM, Escolar ML, Giugliani R, Guffon NH, ... Wraith E. Multidisciplinary Management of Hunter Syndrome. PEDIATRICS. 2009;124(6):e1228-39. doi:10.1542/peds.2008- 
0999.

8. Scarpa M. Mucopolysaccharidosis Type II. 2007 Nov 6 [Updated 2018 Oct 4]. In: Adam MP, Ardinger $\mathrm{HH}$, Pagon RA, et al., editors. GeneReviews ${ }^{\circledR}$ [Internet]. Seattle (WA): University of Washington, Seattle; 1993-2020. Available from: https://www.ncbi.nlm.nih.gov/books/NBK1274/.

9. Richards S, Aziz N, Bale S, Bick D, Das S, Gastier-Foster J, Grody WW, Hegde M, Lyon E, Spector E, Voelkerding K, Rehm HL, ACMG Laboratory Quality Assurance Committee. Standards and guidelines for the interpretation of sequence variants: a joint consensus recommendation of the American College of Medical Genetics and Genomics and the Association for Molecular Pathology. Genet Med. 2015 May;17(5):405-24.

10. Wraith JE, Beck M, Giugliani R, Clarke J, Martin R, Muenzer J. Initial report from the Hunter Outcome Survey. Genet Sci. 2008;10(7):508-16. doi:10.1097/gim.0b013e31817701e6.

11. Sasaki CT, Ruiz R, Gaito R Jr, Kirchner JA, Seshi B. Hunter's syndrome: a study in airway obstruction. Laryngoscope. 1987;97(3 Pt 1):280-5.

12. OMIM - Online Mendelian. Inheritance in Man®; https://omim.org/entry/309900.

13. Orphanet; https://www.orpha.net/consor/cgi-bin/OC_Exp.php?Ing=EN\&Expert=217093.

14. Semyachkina AN, Voskoboeva EY, Zakharova EY, Nikolaeva EA, Kanivets IV, Kolotii AD, ... Melnikova NV. (2019). Case report: a rare case of Hunter syndrome (type II mucopolysaccharidosis) in a girl. BMC Med Genet, 20(1). doi:10.1186/s12881-019-0807-x.

15. Marler JA, Elfenbein JL, Ryals BM, Urban Z, Netzloff ML. Sensorineural hearing loss in children and adults with Williams syndrome. Am J Med Genet part A. 2005;138(4):318-27. 100.

16. Marler JA, Sitcovsky JL, Mervis CB, Kistler DJ, Wightman FL. Auditory function and hearing loss in children and adults with Williams syndrome: Cochlear impairment in individuals with otherwise normal hearing. Am J Med Genet part C. 2010;154(2):249-65.

17. Zarchi O, Attias J, Raveh E, Basel-Vanagaite L, Saporta L, Gothelf D. A comparative study of hearing loss in two microdeletion syndromes: Velocardiofacial (22q11.2 Deletion) and Williams (7q11.23 Deletion) Syndromes. J Pediatr. 2011;158(2):301-6.

18. Khan SA, Mason RW, Giugliani R, Orii K, Fukao T, Suzuki Y, ... Tomatsu S. Glycosaminoglycans analysis in blood and urine of patients with mucopolysaccharidosis. Mol Genet Metab. 2018. doi:10.1016/j.ymgme.2018.04.011.

19. Muenzer J, Beck M, Eng CM, Giugliani R, Harmatz P, Martin R, ... Kimura A. Long-term, open-labeled extension study of idursulfase in the treatment of Hunter syndrome. Genet Sci. 2010;13(2):95-101. doi:10.1097/gim.0b013e3181fea459.

20. Ngu LH, Ong Peitee W, Leong HY, Chew HB. Case report of treatment experience with idursulfase beta (Hunterase) in an adolescent patient with MPS II. Mol Genet Metab Rep. 2017;12:28-32. doi:10.1016/j.ymgmr.2017.05.002. Published 2017 May 11.

21. Wraith JE, Scarpa M, Beck M, Bodamer OA, De Meirleir L, Guffon N, ... Zeman J. Mucopolysaccharidosis type II (Hunter syndrome): a clinical review and recommendations for 
treatment in the era of enzyme replacement therapy. Eur J Pediatr. 2007;167(3):267-77. doi:10.1007/s00431-007-0635-4.

22. Chung YK, Sohn YB, Sohn JM, et al. A biochemical and physicochemical comparison of two recombinant enzymes used for enzyme replacement therapies of hunter syndrome. Glycoconj J. 2014;31(4):309-15. doi:10.1007/s10719-014-9523-0.

23. Kim C, Seo J, Chung Y, et al. Comparative study of idursulfase beta and idursulfase in vitro and in vivo. J Hum Genet. 2017;62(2):167-74. doi:10.1038/jhg.2016.133.

24. Parini R, Deodato F. Intravenous Enzyme Replacement Therapy in Mucopolysaccharidoses: Clinical Effectiveness and Limitations. Int J Mol Sci. 2020;21(8):2975. doi:10.3390/ijms21082975. Published 2020 Apr 23.

\section{Tables}

Figure 2 (Table 1) - Patients with ERT (Elaprase X Hunterase) 


\begin{tabular}{|c|c|c|c|c|c|}
\hline PATIENT & $\begin{array}{l}\text { TYPE OF } \\
\text { ENZYME }\end{array}$ & $\begin{array}{l}\text { ERT } \\
\text { STARTING } \\
\text { AGE }\end{array}$ & $\begin{array}{l}\text { ECHOCARDIOGRAM } \\
\text { BEFORE ERT }\end{array}$ & DURATION & $\begin{array}{l}\text { ECHOCARDIOGRAM } \\
\text { AFTER ERT }\end{array}$ \\
\hline P2 & Elaprase ${ }^{\circledR}$ & $\begin{array}{l}1 \text { year and } \\
5 \text { months }\end{array}$ & Normal & 11 years & Normal \\
\hline P3 & Elaprase $\AA$ & $\begin{array}{l}1 \text { year and } \\
5 \text { months }\end{array}$ & Normal & 11 years & $\begin{array}{l}\text { Mild mitral } \\
\text { insufficiency }\end{array}$ \\
\hline P4 & Elaprase ${ }^{\circledR}$ & 26 years & $\begin{array}{l}\text { Mitral and tricuspid } \\
\text { insufficiency; left } \\
\text { ventricular } \\
\text { hypertrophy }\end{array}$ & 10 years & $\begin{array}{l}\text { Mitral and tricuspid } \\
\text { insufficiency; left } \\
\text { ventricular } \\
\text { hypertrophy }\end{array}$ \\
\hline P5 & Elaprase ${ }^{\circledR}$ & 7 years & $\begin{array}{l}\text { Severe aortic and } \\
\text { mild mitral } \\
\text { insufficiency }\end{array}$ & 11 years & $\begin{array}{l}\text { Mild aortic and mitral } \\
\text { insufficiency }\end{array}$ \\
\hline P6 & Elaprase ${ }^{\circledR}$ & 3 years & Normal & 13 years & $\begin{array}{l}\text { Mild mitral } \\
\text { insufficiency }\end{array}$ \\
\hline P7 & Elaprase ${ }^{\circledR}$ & 8 years & $\begin{array}{l}\text { Moderate aortic } \\
\text { insufficiency }\end{array}$ & 11 years & $\begin{array}{l}\text { Aortic valvar } \\
\text { dysplasia and } \\
\text { regurgitation; left } \\
\text { ventricular dilatation }\end{array}$ \\
\hline P8 & Hunterase ${ }^{\circledR}$ & 29 years & $\begin{array}{l}\text { Mild mitral and } \\
\text { tricuspid } \\
\text { insufficiency }\end{array}$ & 5 years & $\begin{array}{l}\text { Mitral and aortic } \\
\text { valves thickened, with } \\
\text { mild insufficiency }\end{array}$ \\
\hline P9 & Hunterase ${ }^{\circledR}$ & 29 years & $\begin{array}{l}\text { Aortic Insufficiency, } \\
\text { mild to moderate }\end{array}$ & 4 years & $\begin{array}{l}\text { Mild left ventricular } \\
\text { hypertrophy; Diastolic } \\
\text { dysfunction of right } \\
\text { and left ventricle; } \\
\text { Thickening of mitral } \\
\text { and aortic valves; } \\
\text { Mild aortic and mitral } \\
\text { insufficiency }\end{array}$ \\
\hline P10 & Hunterase ${ }^{\circledR}$ & 37 years & $\begin{array}{l}\text { Normal with mild } \\
\text { reflux of tricuspid } \\
\text { valve }\end{array}$ & 4 years & $\begin{array}{l}\text { Concentric left } \\
\text { ventricular } \\
\text { hypertrophy; altered } \\
\text { relaxation of both } \\
\text { ventricles; Thickening } \\
\text { of aortic valves; Mild } \\
\text { mitral insufficiency } \\
\text { and stenosis }\end{array}$ \\
\hline P15 & Hunterase ${ }^{\circledR}$ & 27 years & $\begin{array}{l}\text { Mild thickened and } \\
\text { reflux of mitral and } \\
\text { aortic valves, mild } \\
\text { tricuspid reflux }\end{array}$ & 4 years & $\begin{array}{l}\text { Mild systolic } \\
\text { myocardial } \\
\text { deformation of left } \\
\text { ventricle }\end{array}$ \\
\hline
\end{tabular}


Figure 3 (Table 2) - Patients without ERT

\begin{tabular}{|ll|}
\hline PATIENT & ECHOCARDIOGRAM \\
\hline P1 & Dilated Cardiomyopathy with valvar thickening; aortic and mitral insufficiency (23 years) \\
\hline P11 & $\begin{array}{l}\text { Thickened mitral and aortic valves with mild insufficiency; mild insufficiency of tricuspid } \\
\text { valve (33 years) }\end{array}$ \\
\hline P12 & $\begin{array}{l}\text { Important mitral insufficiency, moderate aortic insufficiency and mild tricuspid } \\
\text { insufficiency (36 years) }\end{array}$ \\
\hline P13 & Mitral and aortic valve insufficiency; concentric left ventricular hypertrophy (34 years) \\
\hline P14 & Mitral valve insufficiency; left ventricular hypertrophy (32 years) \\
\hline
\end{tabular}

\section{Figures}

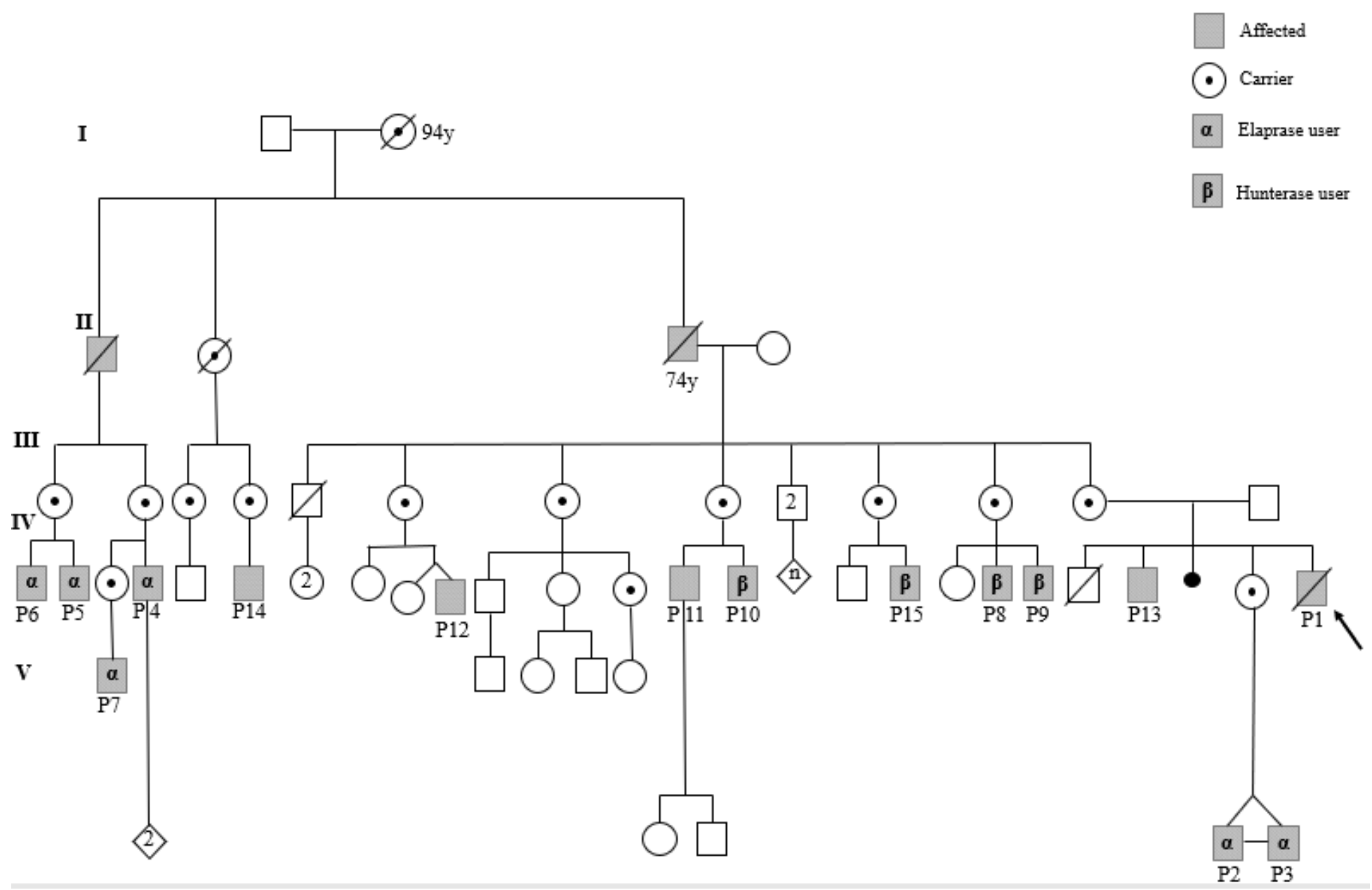

Figure 1

Pedigree 